\title{
Montlivaltia multiformis TOULA (SCLERACTINIA) FROM THE APTIAN OF THE PREBETIC DOMAIN (SE SPAIN)
}

\author{
Elzbieta MORYCOWA', Jean-Pierre MASSE', \\ Consuelo ARIAS $S^{3}$ and Lorenzo VILAS
}

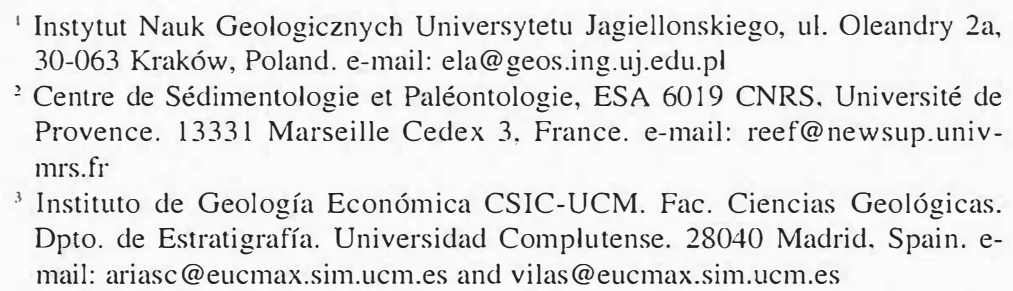

Morycowa, E., Masse, J.P., Arias, C. and Vilas, L. 2001. Montlivaltia multiformis Toula (Scleractinia) from the Aptian of the Prebetic Domain (SE Spain). [Montlivaltia multiformis Toula (Scleractinia) del Aptiense del Dominio Prebético (SE España).] Revista Española de Paleontología, 16(1), 131-144. ISSN 0213-6937.

\begin{abstract}
Montlivaltia multiformis Toula (Scleractinia, Faviina, Montlivaltidae), formerly reported from the Carpatho Balkanic domain is described from Lower Aptian beds of the Prebetic Domain (SE Spain). Taxonomic attributes include the organisation of radial elements, septal trabeculae, carinae and endothecal elements while the external morphology of the coralla is fairly variable. The sedimentological context suggests a circalittoral environment also supported by palaecological features of the surrounding fauna. Owing to its stratigraphic position in the Carpatho-Balkanic region and in Spain, Montlivaltia multiformis appears as a potential marker for both shallow carbonate or outer shelf settings of the Lower Aptian Tethys European margin.
\end{abstract}

Keywords: Scleractinia, Montlivaltia, Aptian, Prebetic Domain, Spain.

\section{RESUMEN}

Montlivaltia multiformis Toula (Scleractinia, Faviina, Montlivaltiidae), originariamente citada en el dominio Carpato-Balcánico, se describe en este trabajo en el Aptiense inferior del Dominio Prebético (SE de España). Las características taxonómicas incluyen la organización específica de sus elementos radiales, septos, trabéculas, carenas y de los elementos de la endoteca, mientras que la morfología externa de la coralita es bastante variable. El contexto sedimentológico en el que se encuadra indica condiciones circalitorales, corroborado por evidencias paleoecológicas de la fauna asociada. Debido a su posición estratigráfica en las regiones Cárpato-Balcánicas y en España, Montlivaltia multiformis Toula se muestra como un marcador potencial del Aptiense inferior de la margen europea del Tetis, tanto para los carbonatos someros como para los de plataforma externa.

\section{Palabras clave: Scleractinia, Montlivaltia, Aptiense, Dominio Prebético, España.}

\section{INTRODUCTION}

The present paper describes specimens of the genus Montlivaltia collected from Aptian outer shelf sediments in Solana del Sopalmo (near Jumilla), South-Eastern Spain (Fig. 1). These specimens constitute a rich monospecific assemblage resembling relatively deep water, dense, solitary, ahermatypic coral communities. Taxonomic attributes and the palaeoecology of these forms are discussed and compared with those corresponding to Montlivaltia species known to date and with modern and Cretaceous "deep water" solitary forms.

Representatives of the genus Montivaltia are common in Jurassic rocks (175 species; Lathuiliere, 1996). Cretaceous species are not too abundant, with only about 40 species described in the literature, 30 of which were identified in Lower Cretaceous sediments. It should be noted that the true species of this genus are probably less common, and most are only varieties that reflect the environmental conditions. Montlivaltia are most 


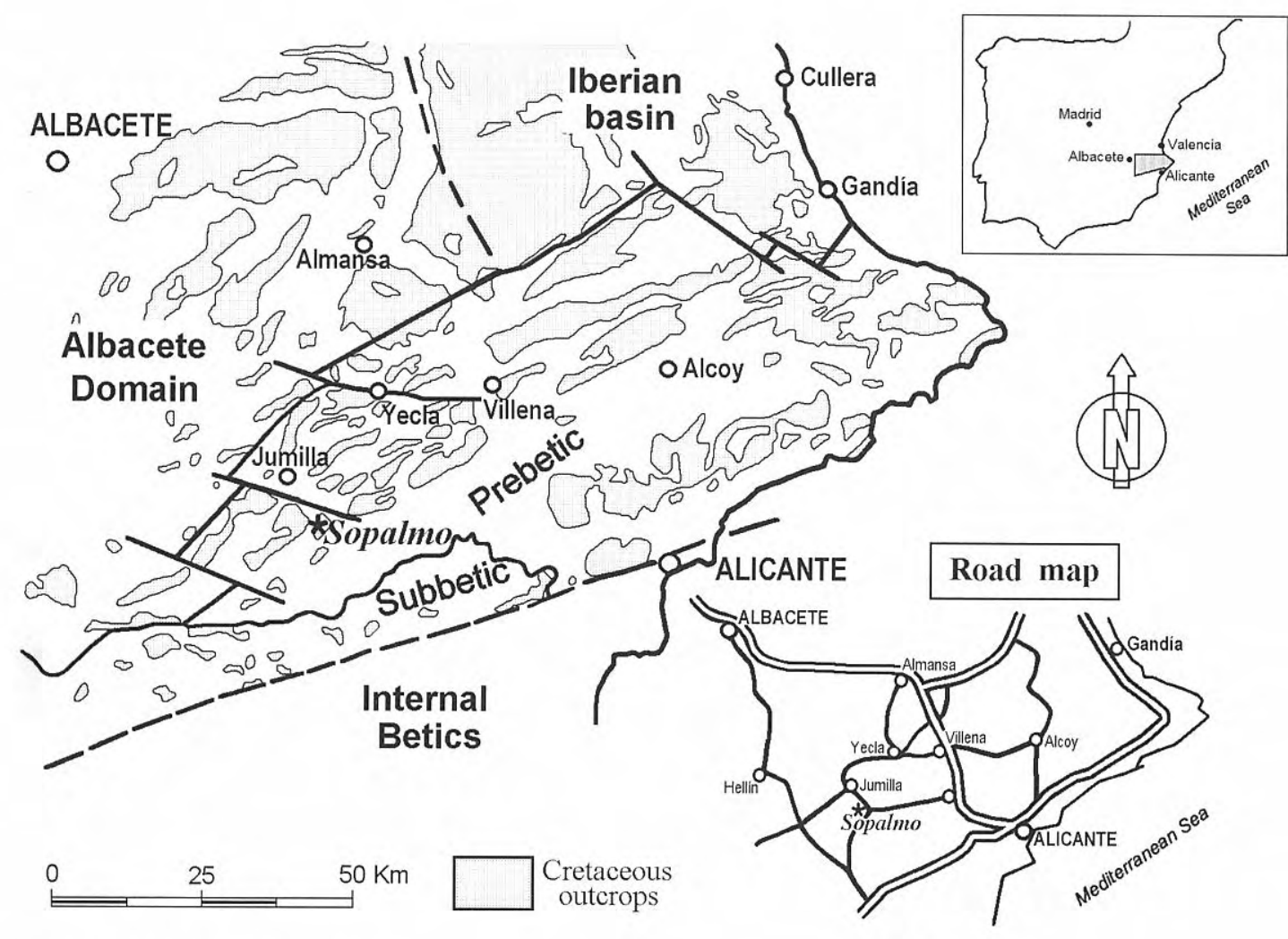

Figure 1. Location of the studied section.

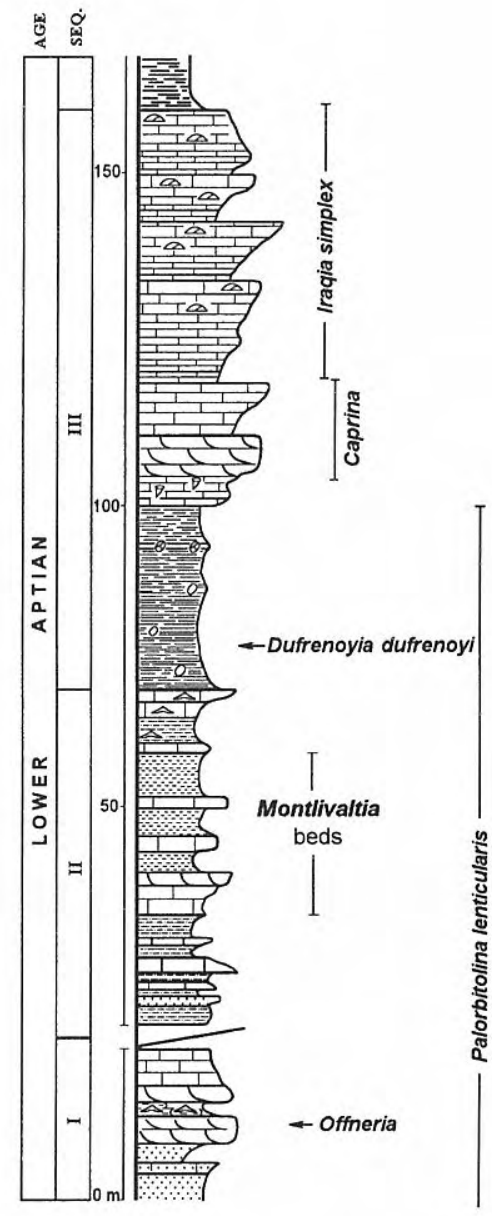

commonly found in coral-rich beds of shallow platform environments and the genus includes a relatively high diversity of scleractinian reef builder ("hermatypic") taxa. Montlivaltia corals may also abundantly occur as a dominant taxon associated with other faunal elements or as a monospecific taxon. For instance, the mass occurrence of Montlivaltia corals, as described here, has also been observed in Aptian marls of Bulgaria (Toula, 1889).

\section{GEOGRAPHICAL AND GEOLOGICAL SETTING}

Specimens were collected from the Aptian beds of Solana del Sopalmo, near Jumilla in SE Spain (Fig. 1). The stratigraphic section of Solana del Sopalmo, formerly described by Arias et al. (1993) and Vilas et al.(1993, 1998) (Fig. 2), is found in the Betic Range and forms part of ENE - WSW faulted fold system, which characterises the tectonic Prebetic Domain in the Jumilla-Yecla region (Vilas et al., 1998). Aptian beds outcrop on the southern flank of the Sopalmo anticline (Vilas et al., 1993) and are comprised of the following sequences (Fig. 2):

I- The lower sequence (about $20 \mathrm{~m}$ thick) starts with coastal clastics followed by packstones with orbitolinids and is capped by packstones containing echinoids and foraminiferids (Praedorothia, Lenticulina). Contact with the overlying unit is faulted. This unit yielded: Offneria sp. (advanced form), Choffatella decipiens Schlumberger and Palorbitolina cf. lenticularis (Blum.).

Figure 2. Stratigraphic section of the Lower Aptian of Solana del Sopalmo. (Modified from Vilas et al., 1998). 

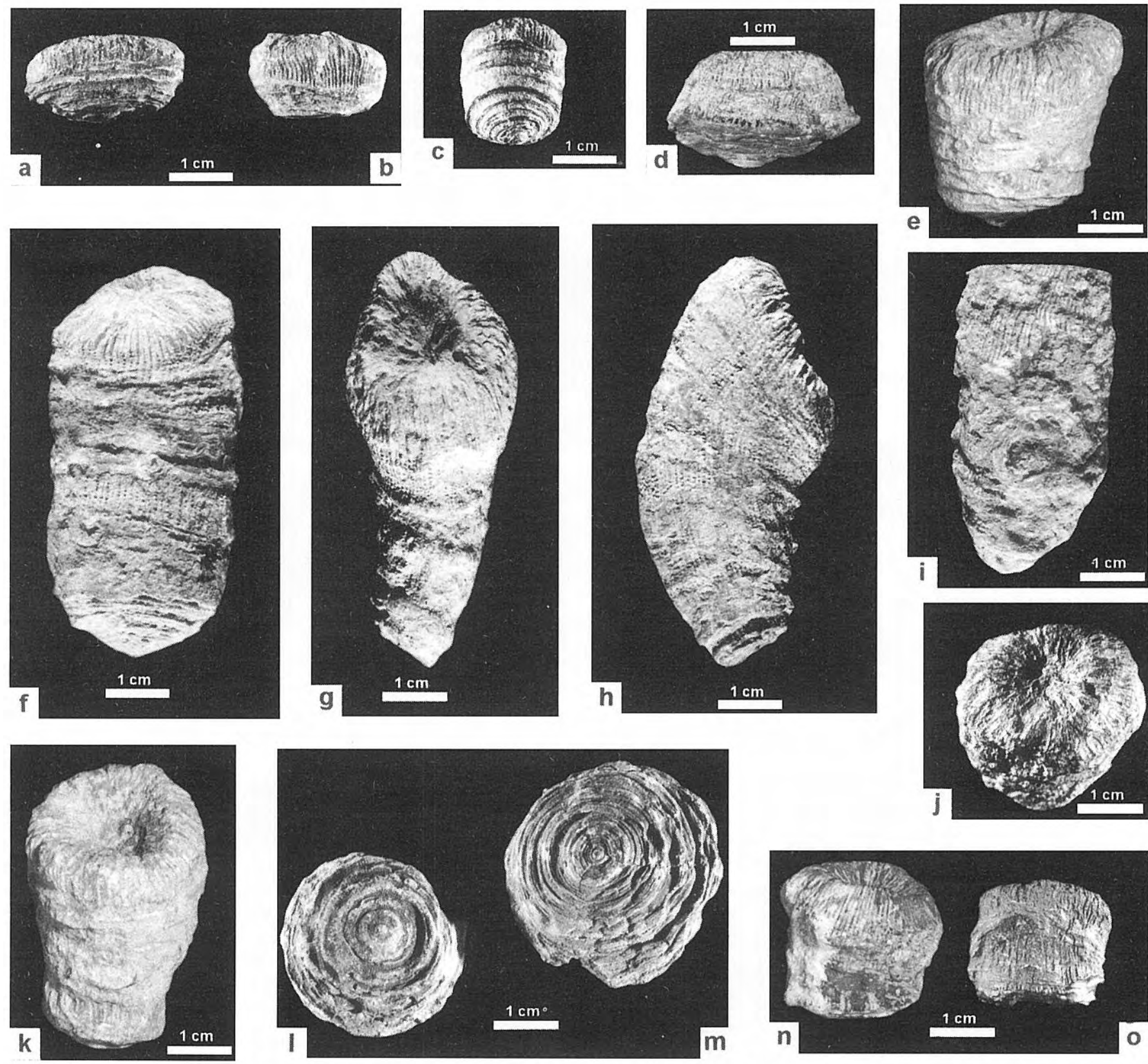

Figure 3. Montlivaltia multiformis Toula. Specimens from Solana del Sopalmo (Spain) -Lower Aptian: a - M38: Side view. b - M37: Side view. c - M40: Side view. d- M13: Side view. e - M7: Side view. f - M5: Side view. g, h - M4: Side view. i - M16: Side view. j - M6: View of upper surface. $\mathbf{k}$ - Side view. $\mathbf{l}$ - M38: View of the lower surface showing marked epithecal wrinkles. $\mathbf{m}$ - M13: View of the lower surface of the specimen presented in d. n - M10: Side view. o - M46: Side view.

II- The middle sequence (about $50 \mathrm{~m}$ thick) is essentially marly. It begins with marls, sands and limestone beds with tempestite sedimentary structures. The sandy beds contain Palorbitolina lenticularis while the carbonate beds yield the bivalves: Plicatula, Aetostreon and Arctostrea. The middle part of the sequence corresponds to the "Montlivaltia marls", and includes sporadic carbonate layers whit glauconite, containing planktic foraminifers (Hedbergella) and deep water benthic forms (Praedorothia, Lenticulina, Epistomina) related to environments located below wave base. The sequence is covered by marls and limestones with Palorbitolina lenticularis, which reflects a shallowing upward trend.
III.- The upper sequence (about $80 \mathrm{~m}$ thick) consists of two different lithological units. The lower unit (about $30 \mathrm{~m}$ thick) is marly, with iron concretions and septaria and contains Dufrenoyia dufrenoyi (d'Orb.). This unit represents an outer shelf sedimentation. The upper unit (about $50 \mathrm{~m}$ thick) starts with colonial (mainly microsolenids) coral beds followed by caprinid rudist beds (Horiopleura, Caprina) and is capped by requienid beds characterised by Iraqia simplex Henson. This sequence represents a shallowing upward stratigraphic succession of an Urgonian type carbonate platform.

In this Lower Aptian succession, the lower sequence is ascribed to the Lower Bedoulian while the middle and the upper sequences are regarded as Upper Bedoulian. The 

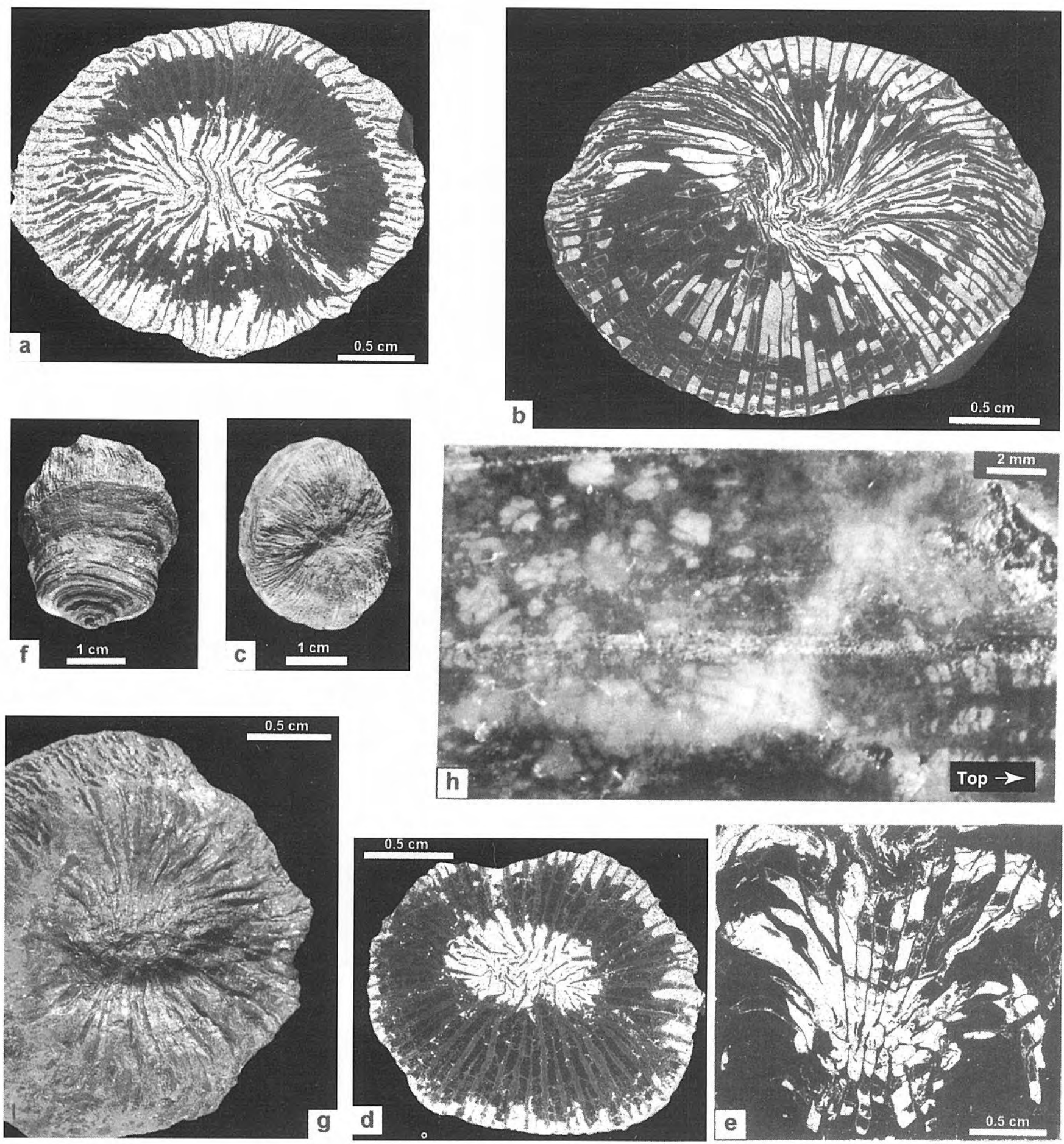

Figure 4. Montlivaltia sp.1, Solana del Sopalmo (Spain) -Lower Aptian: a,e,d. M31: a - Transverse thin section of the upper corallum surface. Note the very thin internal part of the septa. e - Longitudinal thin section of the same corallum showing the scarcity of endothecal elements. $\mathbf{d}$ - Transverse thin section of the lower part of the same corallum. $\mathbf{b}$ M9: Transverse section of the upper part of an adult specimen showing thin and irregularly coiled internal parts of septa, forming a kind of subhelicoidal columella. c - M31: Side view.

Montlivaltia sp. 2, Solana del Sopalmo (Spain) -Lower Aptian: g - M45: Fragment of the calicular surface showing large and deep central fossa and thick, and in places exsert S1 and S2 septa. f- Side view.

Pseudocoenia sp., M50: Solana del Sopalmo (Spain) -Lower Aptian: h - Transverse thin section (photo left) and longitudinal section (photo right).

Montlivaltia marls are ascribed to the Deshayesi ammonite Zone sensu Hoedemaker and Company (1993) while the
Dufrenoyia bearing marls and overlying carbonates pertain to the Furcata Zone (uppermost Bedoulian). 


\section{PALAEOECOLOGY}

The foregoing stratigraphic description, including biological features, shows that the lower sequence and the upper part of the third sequence represent shallow Urgonian type carbonate platform deposits, while the middle sequence, especially the Montlivaltia beds, and the lower upper sequence, represent deeper sediments, i.e. outer-shelf deposits. This interpretation is based on foraminifers, bivalve fauna, sedimentary structures and sequential analysis (Arias et al., 1993). The presence of glauconite in the outer shelf beds can be interpreted as the result of a low to moderate rate of sedimentation.

From a palaeoecological perspective, the Montlivaltia corals from the Lower Cretaceous beds of Solana del Sopalmo occur in a circalittoral setting (sensu Peres and Picard, 1958, in Masse, 1988) and might be compared to some of the documented "deep water" azooxanthellate forms of modern coral fauna such as Caryophyllia smithii Stockes and Broderip (Zibrowius, 1988).

As a solitary, non-constructional form, Montlivaltia multiformis might be considered an azooxanthellate species. Nevertheless, as shown by Zibrowius (1988) some modern non-constructional ahermatypic species like Balanophyllia europaea Risso possess zooxanthellae, while closely related species of similar ecology such Balanophyllia regia Gosse do not have zooxanthellae. Thus, a single species may or may not be associated with zooxanthellae according to the living depth, i.e., zooxanthellae tend to disappear with increasing depth. In general, however, the most recent and probable fossil corals lacking zooxanthellae are solitary and colonial forms with poorly integrated corallites (Coates and Jackson, 1987).

The relative abundance of columnar coralla (Fig. 3) suggests that the growth of $M$. multiformis was able to keep pace with sedimentation. The configuration of the basal part (Fig. 3) suggests a free living mode of growth on a soft substrate, consistent with the surrounding marly sediments. The existence of bent shapes (Fig. 3g, h) indicates the ability of this form to maintain the corallites above the sediment surface after a disturbance or a continuous trend of downwarping during growth, caused by weight excess relative to the substrate's internal mobility, as documented for modern Caryophyllia (Zibrowius, op. cit.).

Figure 5. Montlivaltia multiformis Toula, Lower Aptian. Side view of coralla with marked uppermost epithecal extension (=concentric epithecal wrinkles): A-G, I - Specimens of Aptian sediments of Bulgaria: A-G - Schematic figures based on illustrations presented by Toula (1889, p1. 6, Fig. 8a-d), I - based on a photograph provided by Roniewicz and Stolarski (1999, fig. 10B); $\mathbf{H}$ - based on a picture of a specimen presented by Morycowa (1971, pl. 15, Fig. 3a) from the Lower Aptian marls of Romanian Carpathians; J-R - Specimens from Lower Aptian sediments of Solana del Sopalmo (Spain).
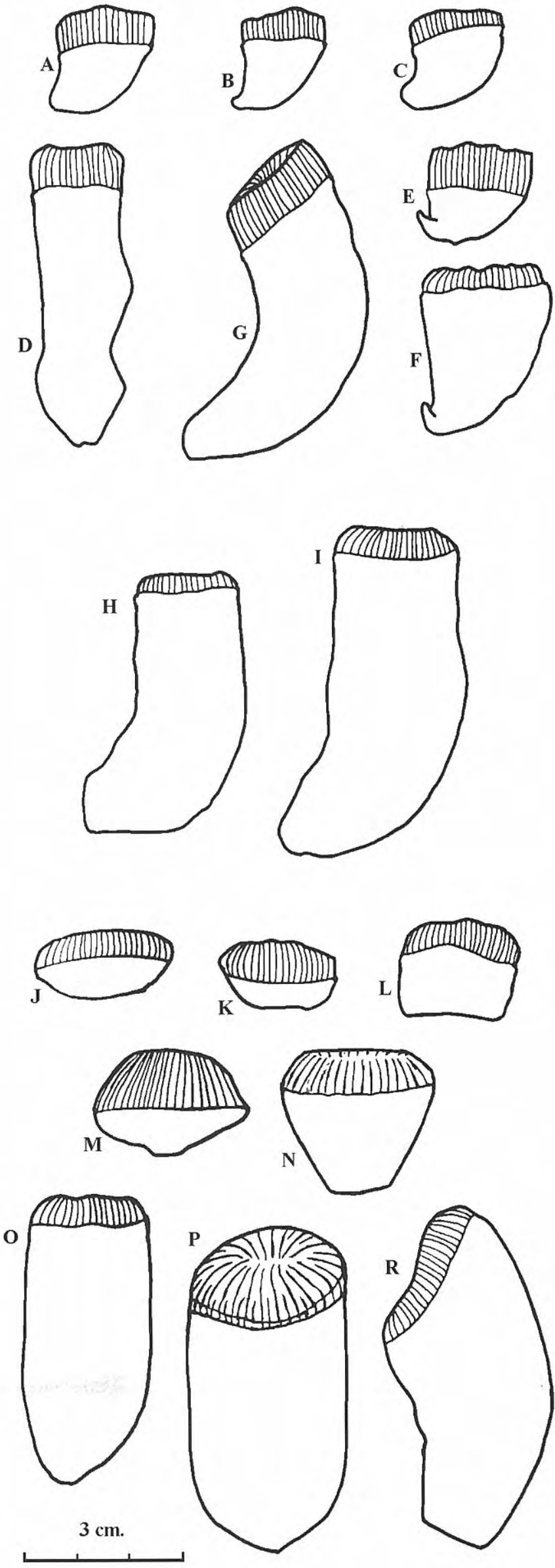


\begin{tabular}{|c|c|c|c|c|c|c|c|c|c|c|c|c|}
\hline \multirow{12}{*}{$\mathbf{H}$} & 61-65 & & & & & & & 1 & & 1 & & \\
\hline & $56-60$ & & & & & & & 1 & & & & \\
\hline & $51-55$ & & & & & 1 & & & & & & \\
\hline & $46-50$ & & & & 1 & & & 2 & & & & 1 \\
\hline & $41-45$ & & & & & & & & 2 & & & \\
\hline & $36-40$ & & & & 1 & & 1 & 2 & 1 & 1 & & \\
\hline & 31-35 & & & & 1 & 1 & 2 & & 1 & & & \\
\hline & $26-30$ & & & 1 & 1 & 2 & 2 & 1 & & 1 & & \\
\hline & $21-25$ & & 1 & & & 2 & 2 & & & & & \\
\hline & $16-20$ & & & 1 & 2 & & 1 & 1 & 2 & & & \\
\hline & $10-15$ & 1 & 1 & 1 & 2 & & & & & & & \\
\hline & & $15-16$ & 17-18 & $19-20$ & $21-22$ & $23-24$ & $25-26$ & $27-28$ & $29-30$ & 31-32 & 33-34 & $35-36$ \\
\hline
\end{tabular}

Figure 6. Correlation between greater diameter (D) and heigh (H) of 46 coralla of Montlivaltia multiformis Toula from Lower Aptian sediments of Solana del Sopalmo .

Assuming that Pseudocoenia d'Orbigny was a hermatypic photophylic (requiring high illumination) form, the Montlivaltia-Pseudocoenia association suggests that Pseudocoenia might have been expanding downwards to depths corresponding to the circalittoral zone (i.e. several tens of meters) and/or Montlivaltia was thriving mainly in a circalittoral context with possible upward expansion to the infralittoral-circalittoral boundary (i.e., the boundary between zones of poor and high illumination). A similar palaeoecological assemblage including solitary corals such as Montlivaltia, Paramontlivaltia and Peplosmilia, together with the shallow water colonial Dimorphocoenia, was described from the Crimean Valanginian (Kuzmicheva, 1963).

\section{MATERIAL AND METHODS}

The coral assemblage contains 50 specimens, 49 of which are solitary and only one colonial. This colony (shaped as a solitary trochoid coral) is plocoid but on account of its very poor state of preservation was identified at the generic level only as a species of the genus Pseudocoenia (Stylinidae) (Fig. 4h). All the solitary corals were identified as belonging to the Montlivaltia genus. These corals occur in various forms, especially as regards to their shape (subdiscoid, subtympanoid, subturbinate, subtrochoid, subcylindric, cuneiform; Fig. 5, Fig. 3), height (from $1 \mathrm{~cm}$ to about $6 \mathrm{~cm}$; Fig. 6, Fig. 3), calice diameter (greater diameter from 16 to $35 \mathrm{~mm}$; Fig. 7) and size of the base (from ca. $1 \mathrm{~cm}$ to $2.5 \mathrm{~cm}$; Fig. 3). The initial stages of the coralla are round, only slighty convex, about 1-1.3 mm in diameter (Fig. 31 , m. Fig. 8 d - e). The planula were settled on little grains, rarely on serpula and bryozoan remains. The coralla do not show signs of abrasion. Traces of organism boring are rare. The skeletons are on rare occasion "encrusted" by serpulids and oyster shells.

Light microscopy (18 thin sections) and scanning electron microscopy examination (SEM) of skeletons indicated that the skeletons had recrystallized but traces of the original microstructure and ornamentation of the radial elements were preserved in places (Fig. 4 b-e, Fig. 9 f, 12 b).

Montlivaltia specimens are deposited in the Geological Museum of the Geological Institute at the Jagiellonian University, Kraków, Poland with the number UJ 164P.

\section{Abbreviations used in the descriptions :}

D- calicular diameter, D1- greater calicular diameter (in $\mathrm{mm}$ ), D2- lesser calicular diameter (in $\mathrm{mm}$ ), $\mathrm{H}$ corallum height (in $\mathrm{mm}$ ), CS- number of costosepta per calice at the upper edge of corallum, S1-Sn- septa of

\begin{tabular}{|r|r|r|r|r|r|r|r|r|r|r|c|}
\hline 8 & & & & 8 & & 8 & 8 & & & & \\
\hline 7 & & & & & & & & & & & \\
\hline
\end{tabular}

Figure 7. Frequency distribution (N) of calicular greater diameter (D) of 46 specimens of Montlivaltia multiformis Toula from Lower Aptian sediments of Solana del Sopalmo. 

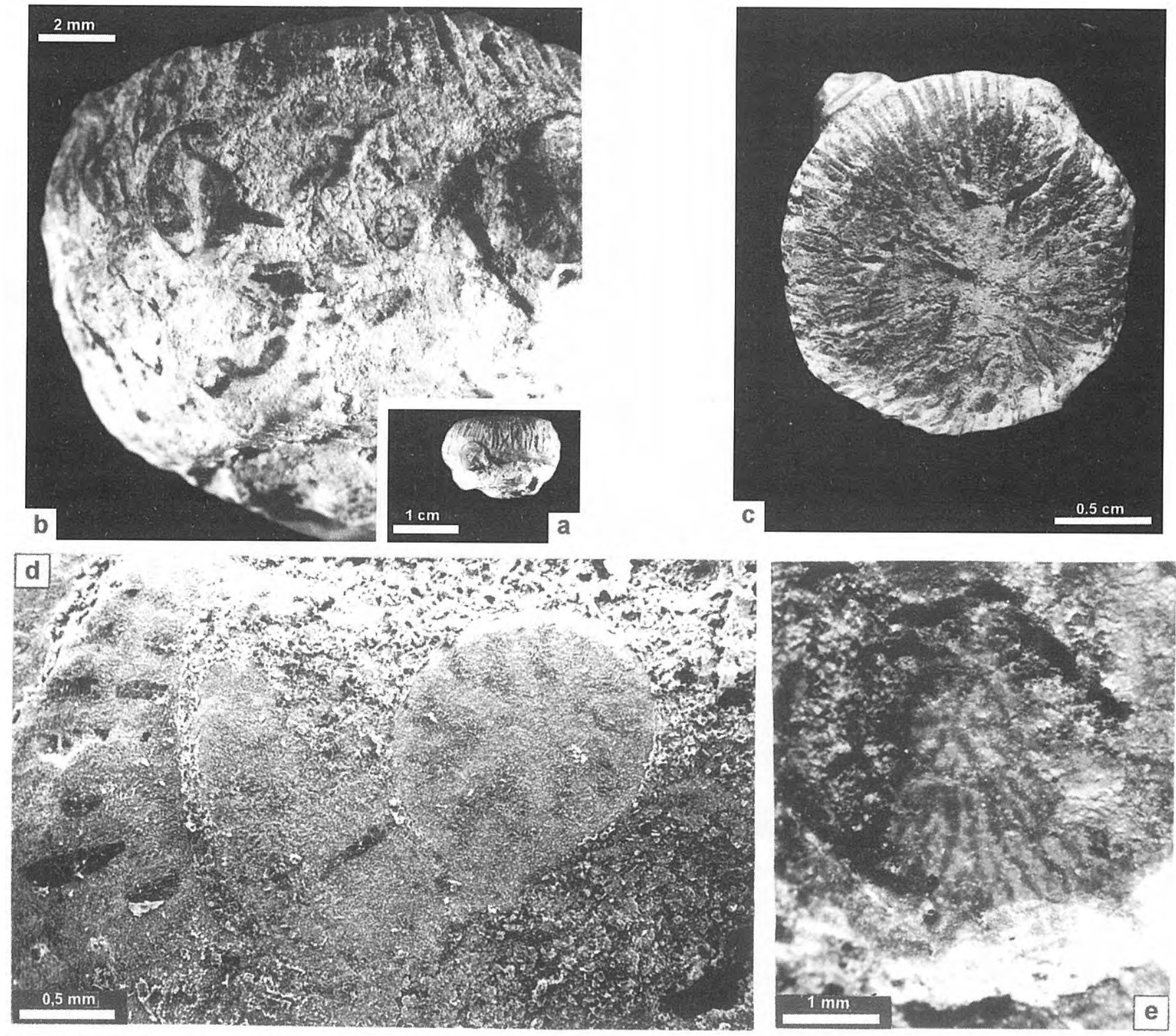

Figure 8. Montlivaltia multiformis Toula, Solana del Sopalmo (Spain) -Lower Aptian: a - c, M41: a - Side view of corallum. b - Part of the same lateral surface showing traces of attachment and initial stage in the development of the corals, probably of the Montlivaltia genus. c - Calicular surface of the same specimens. d - M27: View of the lower surface of corallum showing early-juvenile part of specimen with two cycles of radial elements and three thecal rings (SEM). e - Early-juvenile stage of corallum with two cycles of radial elements (polished surface).

succeeding cycles, CS1...CSn- costosepta of succeeding cycles, dcs- density of costosepta per $5 \mathrm{~mm}$ (upper edge of corallum), thcs- thickness of costosepta near the upper edge of calice (mm), dcar- density of carenae (per $2 \mathrm{~mm}$, lateral surface of septa), dcgr- density of costal granules (per $5 \mathrm{~mm}$, lateral surface of corallum), itdintertrabecular distance ( $\mu \mathrm{m}$; transverse section), denddensity of endothecal tabuloid elements (per $5 \mathrm{~mm}$; in longitudinal section), (...)- rare occurrences.

Lateral thecal faces (after Cairns and Wells, 1987) = two broad edges of an elliptical calice.

Lateral thecal edges - two narrow thecal edges of an elliptical calice.

Morphological terms for growth forms of Spanish specimens: 1- subdiscoid, 2- subtympanoid, 3subcupolate, 4- subcylindrical, 5- subturbinate, 6subtrochoid arcuate, 7 subtrochoid, 8- cuneiform.

\section{TAXONOMY}

ORDER SCLERACTINIA Bourne, 1900

SUBORDER FAVIINA Vaughan and Wells, 1943

Family Montlivaltiidae Dietrich, 1926, emend. Alloiteau, 1952

Genus Montlivaltia Lamouroux, 1821, emend. Gill and Lafuste, 1971 

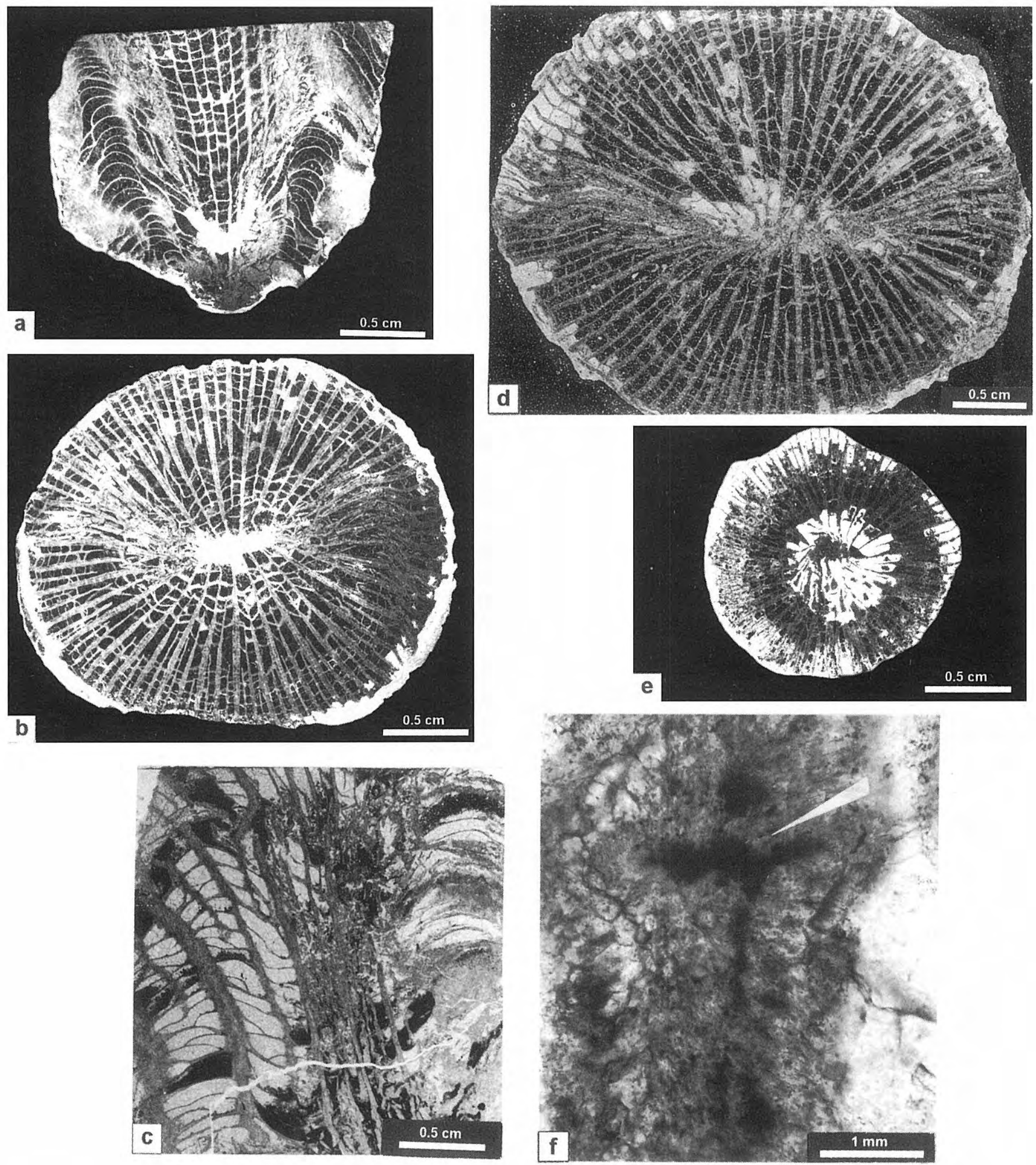

Figure 9. Montlivaltia multiformis Toula, Solana del Sopalmo (Spain) -Lower Aptian: a, b. M8: a - Longitudinal section of the lower part of the corallum showing the arrangement of tabuloid endothecal elements. b -Transverse section of the adult corallum with 100 radial elements arranged in 4 size orders ( 5 complete cycles and an incomplete 6th cycle). c, d - M2: c - Longitudinal section. d -Transverse section of the adult corallum with 112 radial elements. e M48: Transverse section of a small specimen. $\mathbf{f}$ - M39: Detail of transverse thin section of septum showing the traces of the microstructure. Arrow indicate the rhomboid trabecula (= main trabecula with lateral trabeculae). 


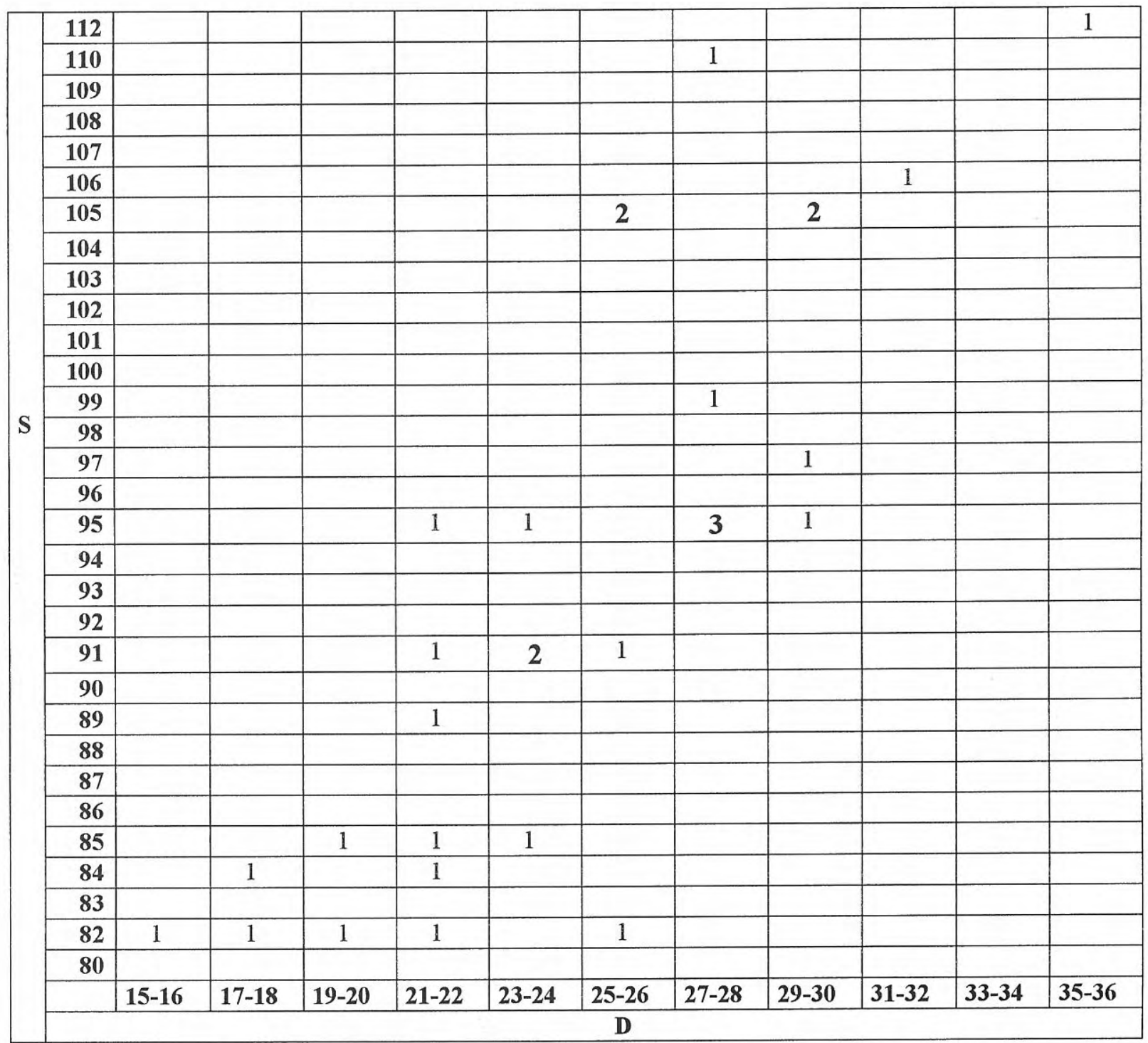

Figure 10. Relationships between radial elements (S) and calicular diameter (D) of 32 coralla of Montlivaltia multiformis Toula from Solana del Sopalmo. Only specimens with radial elements that could be calculated were considered.

Type species: Montlivaltia caryophyllata Lamouroux, 1821.

About 30 species of Montlivaltia from the Lower Cretaceous have been described: d'Orbigny (1850), Fromentel (1857, 1863 -1867), Trautschold (1886), Solomko (1888), Toula (1889), Koby (1896-98), Angelis d'Ossat (1905), Dietrich (1926), Wells (1946), Bataller (1947), Eguchi (1951), Kolosvary (1954), Alloiteau (1958), Kuzmicheva (1963), Morycowa (1971), Liao (1982), Liao and Xia (1985), Bugrova (1991). Identification of the Montlivaltia species is not an easy task since species descriptions provided in the literature are not sufficiently precise. Moreover, many paleontologists regarded corallum shape as one of the diagnostic features and consequently described too many species. We consider the morphological shape of the Montlivaltia multiformis coralla discussed here to be within the range of variation of this species and treat it not as a diagnostic but rather an ecophenotypic feature. Adopted criteria for systematic discrimination were: development, number and symmetry of radial elements, diameter and density of septal trabeculae and carinae and density of endothecal elements, see Alloiteau (1957, 1958), Gill and Lafuste (1971).

\section{Montlivaltia multiformis, Toula 1889}

Figs. 3, 5-12, 13 a-e

1889 Montlivaltia multiformis Toula, 87, pl. 6, fig. 8 .

1971 Montlivaltia multiformis Toula; Morycowa, 75-76, pl. 15, fig. 3.

1999 Montlivaltia multiformis Toula; Roniewicz and Stolarski, fig. 10A-D.

Material: 46 specimens: No: M1-8, 10-30, 32-44, 46-48; 13 thin sections.

Dimensions (in mm)

D1 -

16-35 


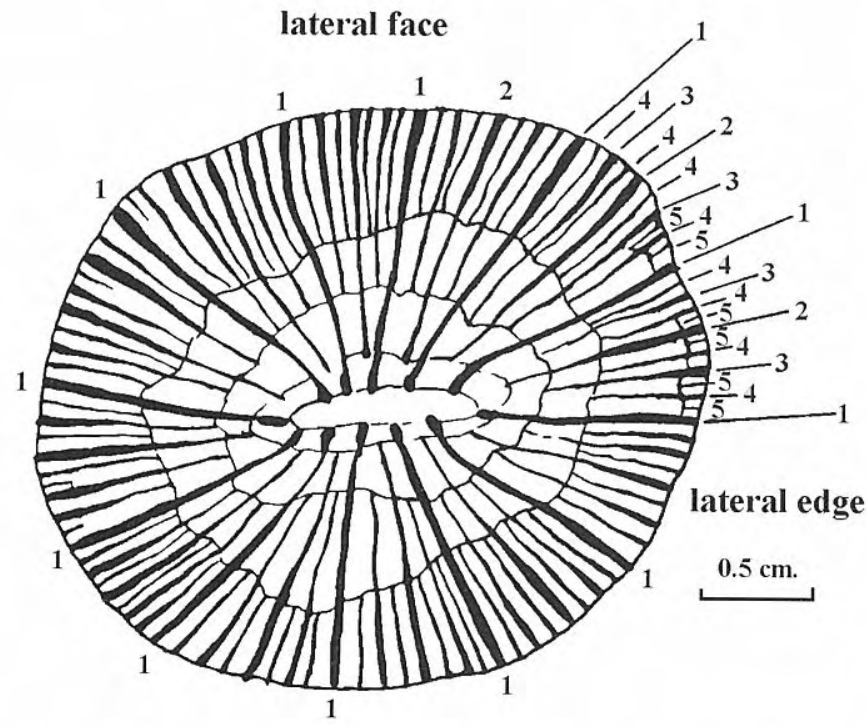

Figure 11. Schematic cross-section of an adult specimen of Montlivaltia multiformis from Solana del Sopalmo illustrating the five complete cycles (1-4 in the figure) and the 6th incomplete cycle (5 in the figure) of radial elements. The thickening of the axial ends of septa of first size orders (S1 and S2) (1 in the figure) and the narrow, elongate central space are marked.

$\begin{array}{ll}\text { D2 - } & 12-30 \\ \mathrm{H}- & 10-61 \\ \text { CS - 82 - 112 (5 complete + an incomplete 6th cycle) } \\ \text { ths CS1, CS2- } & 0.3-0.4(0.5) \\ \text { ths CS3, CS4 } & 0.25-0.4 \\ \text { ths CS5-CS6- } & 0.1-0.2 \\ \text { dCS- } & 6-9(\text { in places: } 10-11) / 5 \mathrm{~mm}) \\ \text { dcar CS1-S3 } & \text { (4) } 5-7(8) / 2 \\ \text { itd CS1-CS3 } & \text { ca. } 250-400(500) \mu \mathrm{m} \\ \text { itd CS5 } & \text { ca. } 250-300 \mu \mathrm{m} \\ \text { dcgr- } & 3-4(5-6) / 2 \\ \text { dend- } & 6-8 / 5\end{array}$

\section{Description}

Coralla range from discoid to subtympanoid, subtrochoid, subturbinate and subcylindrical, and are occasionally only slightly curved in the lower part (Figs. 3 and 5). Epitheca transversally wrinkled, partly covering the lateral surface of the coralla but not reaching the edge of the calice. Calicular surface almost flat to moderately convex or concave, subelliptical, rarely circular, with a broadly rounded upper margin (Fig. $8 \mathrm{a}-\mathrm{c}$ ). In rare cases, large axial fossa occur. Base of corallum mainly broad, flat or slightly convex. Twelve radial elements $(6+6)$ are observed in the early corallite stage of diameter ca. $1 \mathrm{~mm}$ (Fig. $8 \mathrm{~d}$, e). The diameter of the upper part of the coralla ranges from 16 to $35 \mathrm{~mm}$, and height from 10 to ca. $60 \mathrm{~mm}$. Eighty two to 112 costosepta are arranged in hexameral symmetry (in adult forms from 5 complete to 6- incomplete cycles) (Fig. 9 b, d, e, Fig. 12 a). In the periphery of the coralla every other radial element is usually much thinner (Fig. 11). The number of septa increases during corallum growth, from about 82 in forms with a diameter of $16 \mathrm{~mm}$ to $102-112$ in those with a diameter of 32-35 mm. S1 and S2 septa (first two cycles) are equal and approach the corallum axis. Their internal ends are slightly thickened (subrhopaloid septa). These septa, arranged in an oblique position with respect to the greater dimension of the axial space, have curved ends. The S3 septa are only slightly shorter than S1 and usually without the thickened end; S4 septa reach up to half or three-quarters of S1 septa; S5 septa are over a third of S1.They are much thinner and shorter than S1-S4 (Fig. 12 b, c). In some coralla, short and thin S6 costosepta occasionally occur. The upper margin of the costosepta is denticulate and lateral surfaces are carinate. Alternate costae, thin and thick, in places subequal, are distinctly dentate. Endotheca consists of thin-walled, large tabuloid elements, strongly concave at the centre and convex in the corallite periphery (Fig. 9 a, c).

\section{Microstructure}

The skeletons are not well preserved. However, in many places, traces of the skeletal microstructure are visible (Fig. 9 f). Distances between large "rhomboid" trabeculae (= main, primary trabecula with secondary lateral ones) in transverse sections of the S1-S3 costosepta are from ca. 250 $\mathrm{mm}$ to $400 \mu \mathrm{m}$ (rarely from 80 to 500 ), depending on the size of the costoseptum. Lateral trabeculae are expressed on the lateral surface of costosepta as simple carinae and as double carinae in places (Fig. $13 \mathrm{~d}$ ). In the periphery of the radial elements, these are stronger than those further inside the elements. The density of the carinae is mainly $4-6$ in the external part of S1-S4 costosepta, and 6-7 in their interior as well as in the costosepta of highest cycles. In some lateral surfaces of radial elements, rows of granules, corresponding to trabeculae arranged in a single fan system, can be observed.

Distribution: Solana del Sopalmo (Prebetic domain, SE Spain) - Aptian. Tirnovo, Orese (Balkan Foreland, Bulgaria) - Aptian.

\section{Remarks}

Specimens from the Lower Aptian of Spain belong to the species Montlivaltia multiformis described in the Aptian marly sediments of the Balkan Foreland (Toula, 1889). One of the authors (E. M.) had the opportunity to observe the corresponding Aptian coral-bearing marly sediments in Tirnovo (Balkan Foreland), thanks to the kind invitation of Dr Vassil Zlatarski, and in Prof. E. Roniewicz's collection. The most important features common to both groups of specimens of this species are: 1- the initial septal phase in the development of radial elements, 2- the development and density of radial elements in adult specimens, and 3- the density of septal trabeculae and carinae (see Fig. 13 h). However, there are also some differences between the assemblages of Spanish and Bulgarian specimens. Most of the Bulgarian corals are smaller and the initial shape of their coralla is commonly narrow and curved (Toula, 1889 , pl. VI, fig. 8; see also our Fig. 13g). This feature may be connected with conditions of life during the first stages of growth. 


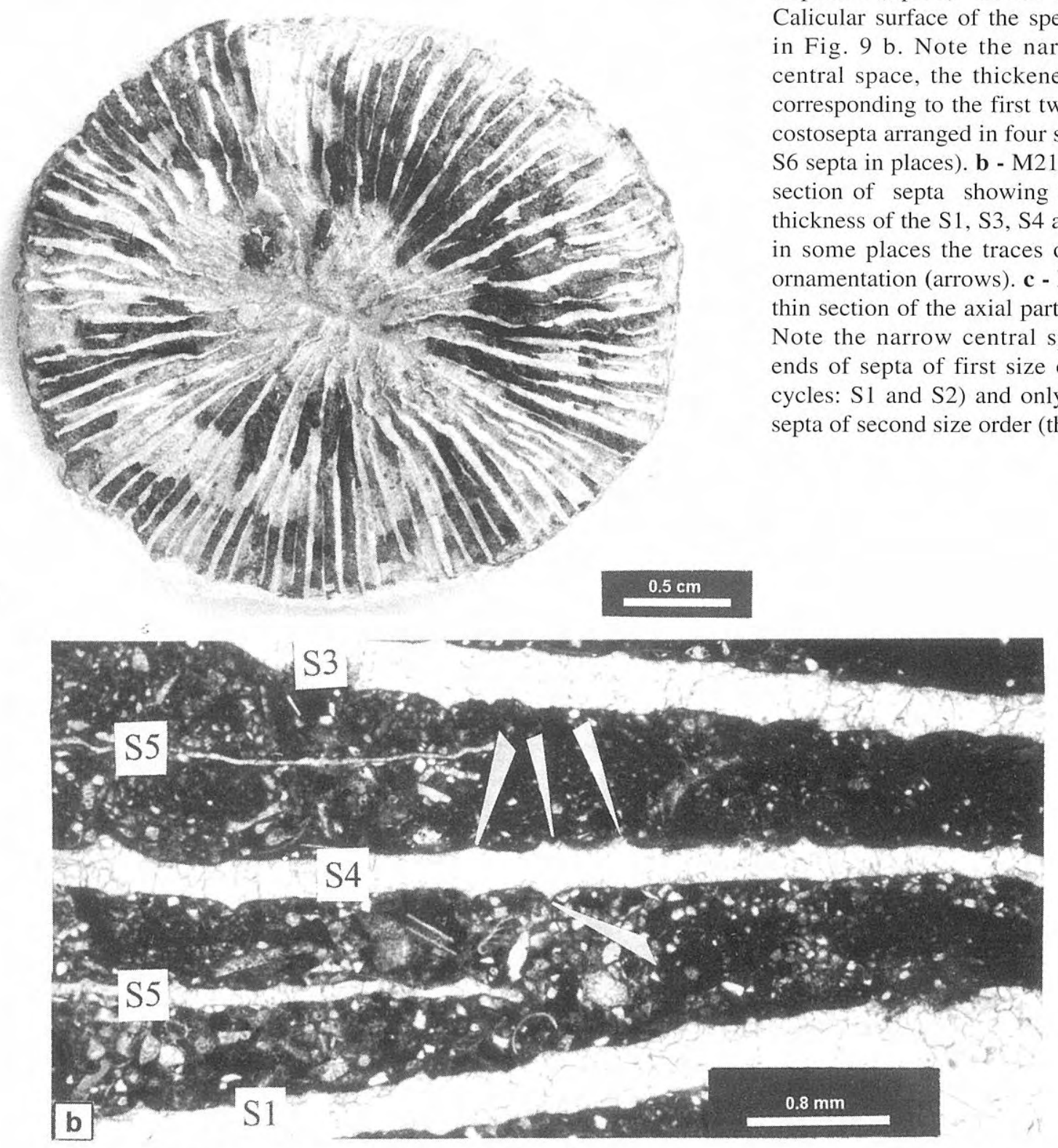

Figure 12. Montlivaltia multiformis Toula, Solana del Sopalmo (Spain) -Lower Aptian: a - M8: Calicular surface of the specimen presented Fig. 9 b. Note the narrow, elongated section of septa showing the difference in S4, S4 and S5 septa, and Note the narrow central space, thickened first size orders (first two ycles: S1 and S2) and only slightly shorter epta of second size order (third cycle: S3).

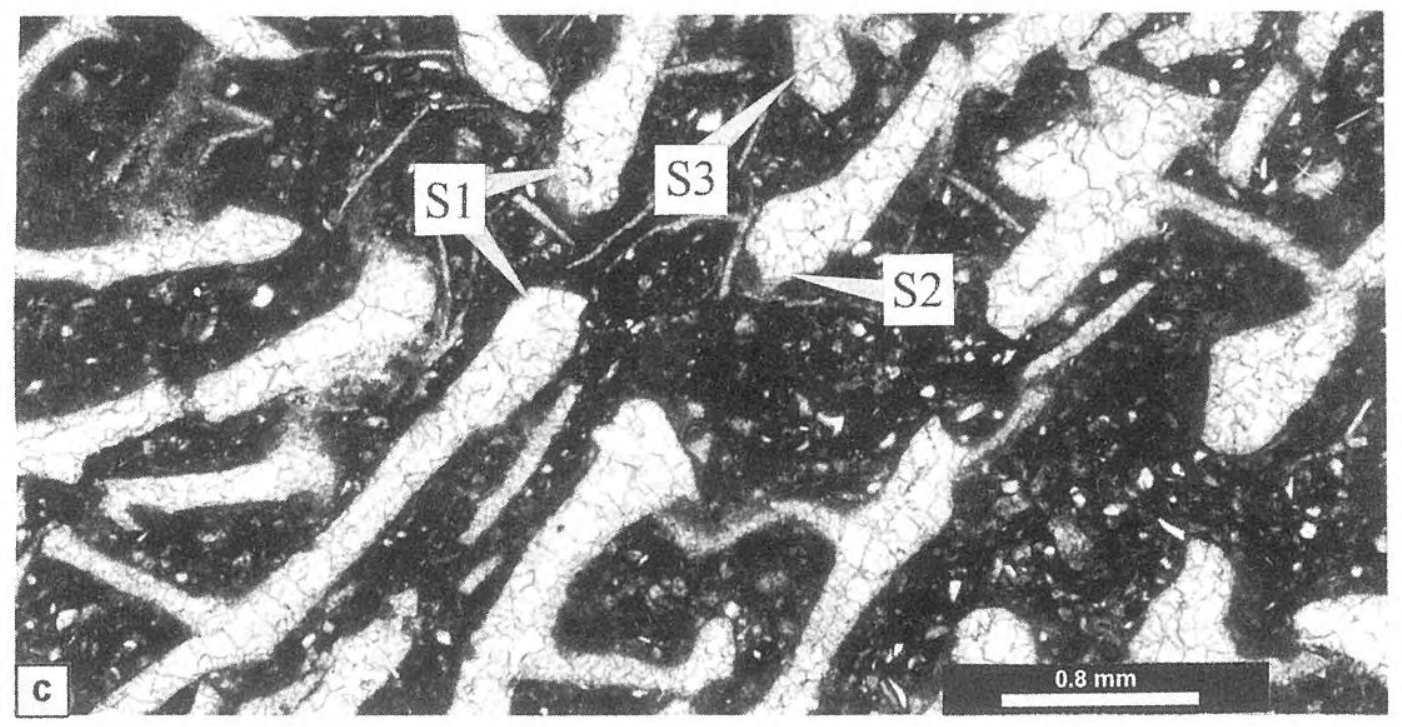



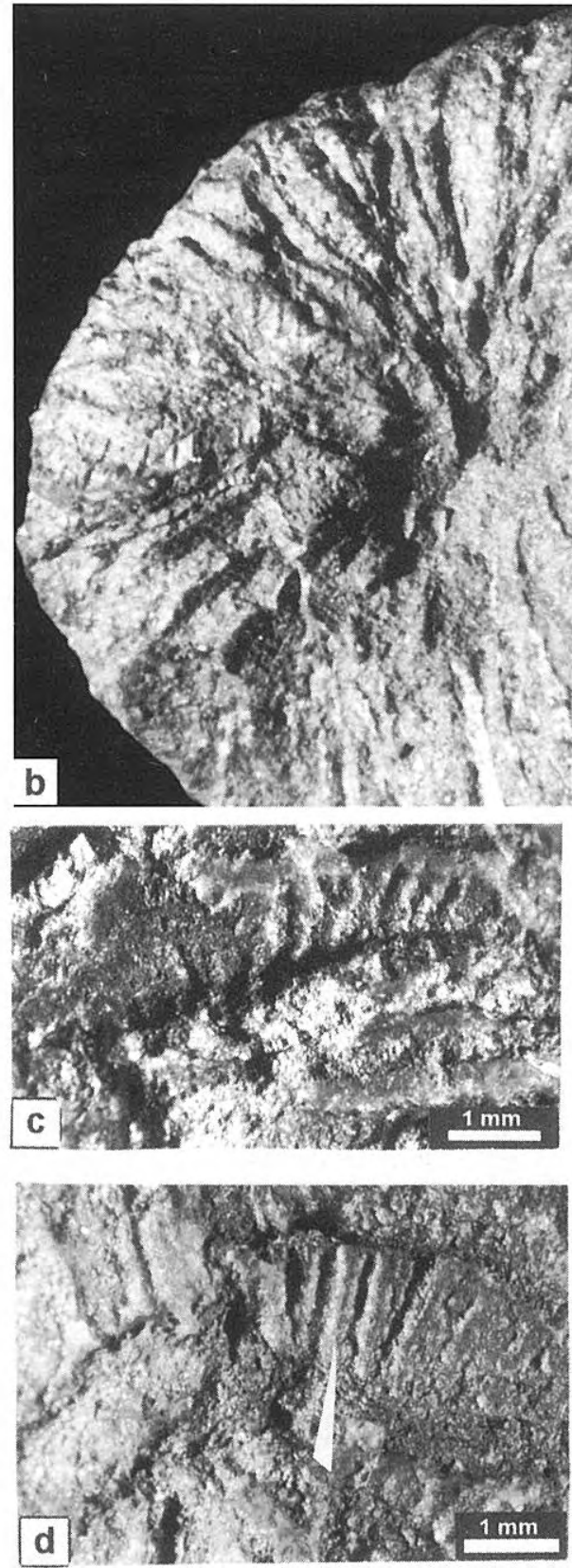

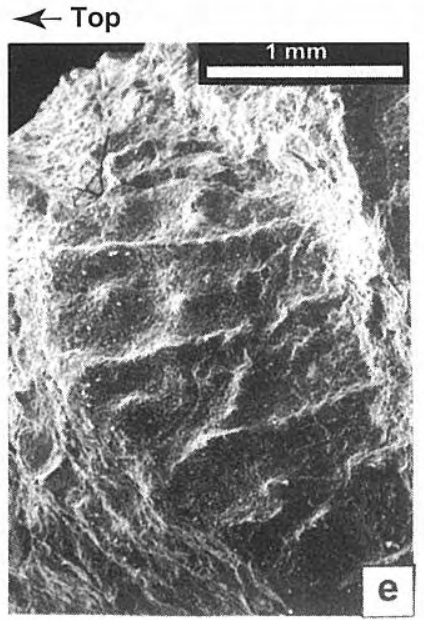

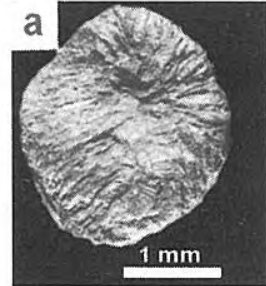

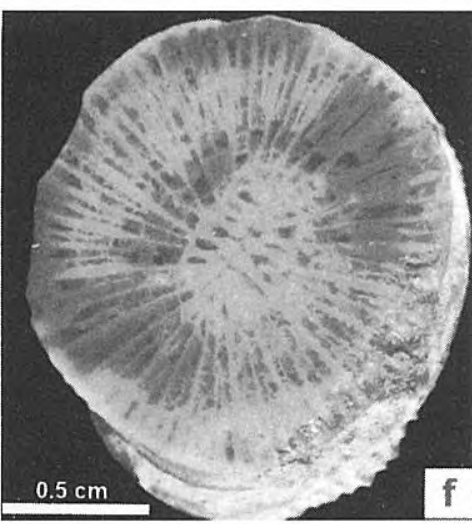

$\mathrm{f}$

.
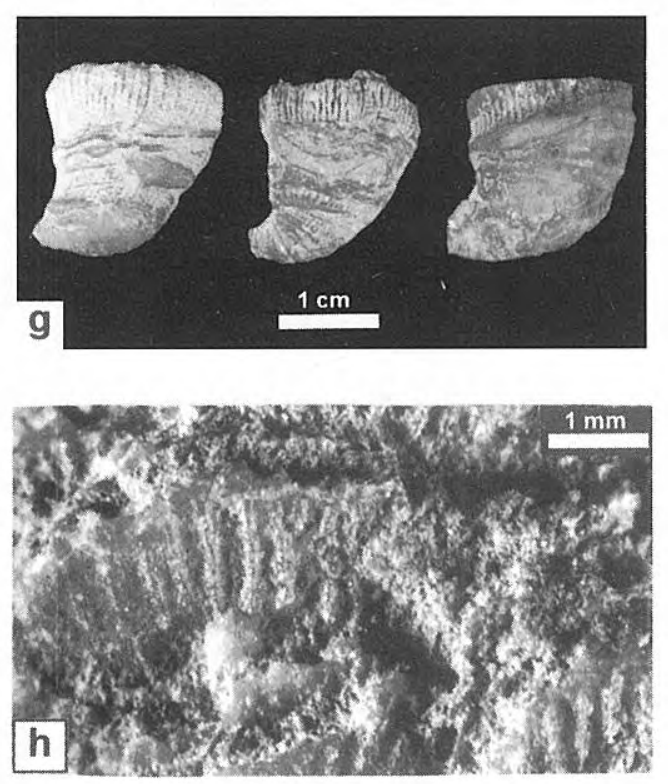

Figure 13. Montlivaltia multiformis Toula, Solana del Sopalmo (Spain) - Lower Aptian: a - e. M46: a - Calicular surface of a small specimen. b - Enlargement of the same calicular surface showing arrangement of the carinae on the upper lateral surface of some costosepta (arrows). c, d, e - Details of b: Note slightly different forms of carinae: single carinae in $\mathbf{c}$, single and double (arrow) in $\mathbf{d}$ and striae and granules in $\mathbf{e}$.

Montlivaltia multiformis Toula, Tirnovo (Bulgaria) - Lower Aptian: f - h. f - Polished upper surface of corallum showing distinct thickening at the internal ends of the septa of first size order and a slightly less developed thickening in the septa of second size orders. $\mathbf{g}$ - Small coralla with carved lower part. $\mathbf{h}$ - Lateral surface of septum with single and double carinae.

Also, most of the Bulgarian specimens have fewer septa (72-96) and the first two cycles of septa are relatively thickened at their axial ends (Fig. $13 \mathrm{f}$ ).

Montlivaltia multiformis resembles $M$. icaunenis d'Orbigny, 1850 (Fromentel, 1863, pl. 42, fig. 2, 2a, 2b; not pl. 81, fig. 1, 1a, 2, 2a and pl. 78, fig. 3, 3a) from the Hauterivian of France. Nevertheless, it differs from the latter in that adult forms show more numerous radial elements (our adult specimens have 5 complete cycles and a 6th incomplete cycle and those from France have only 5 complete cycles $=96$ radial elements . Unfortunately, we have no information on the microstructure and density of the septal carinae of the French specimens.

The present species are also morphologically similar to $M$. burckhardti Wells from the Hauterivian sediments of Mexico (Wells, 1946). Perhaps the Mexican species is a young synonym of $M$. icaunenis. The lack of precise 
description does not permit a more detailed comparison.

M. multiformis shows some affinity to M. superficialis Alloiteau from the Albian of Madagascar, but according to Alloiteau (1958), radial elements (96) in this species are arranged in octomeral symmetry.

\section{Montlivaltia sp. 1}

Fig. $4 \mathrm{a}-\mathrm{e}$

Material: 2 specimens: No: M9 and M31; 4 thin sections.

\begin{tabular}{lcc} 
& No M9 & No M31 \\
Dimensions (in mm): & 23/30 \\
D1/D2 & max. 44 & 50 \\
H - & $96(5$ cycles $)$ & $106(5$ complete \\
CS - & \multicolumn{3}{c}{ cycles + an incomplete } \\
& 6th cycle $)$ \\
ths CS1- S4 & $0.2-0.30$ & $0.25-0.30(0.40)$ \\
th CS5-S6- & $0.10-0.15(0.20)$ & $0.07-0.10(0.15)$ \\
dcs- & lateral face: $5-6 / 5 ;$ \\
\multicolumn{3}{c}{ lateral edge: $9-11 / 5 \mathrm{~mm}$} \\
dcar- & $0.25-0.63$ & $6-8 / 5$ \\
itd S1 & $250-300 \mu \mathrm{m}$ & $250-300(400) ; 400-700 \mu \mathrm{m}$ \\
itd S4-S5 & $100-200 \mu \mathrm{m}$ & $70-100(150) \mu \mathrm{m}$
\end{tabular}

\section{Description}

Coralla subtrochoid, subturbinate. Calice shallow with slightly marked narrow, central fossa. Costosepta arranged hexamerally in four complete cycles. Occasionally, several costosepta of 6th cycle occur. The internal part of the 12 large septa (first two cycles) and an equal number of the third cycle interfinger or coil and form a sort of parietal, helicoid columella. The axial ends of these septa are generally thin, without thickening. Endotheca not abundant. Epitheca partly covering the lateral surface of the coralla but not reaching the edge of the calice.

\section{Remarks}

These species differs from M. multiformis in its distinctly thinner axial part of the septa and in that it has an axial structure similar to that of the parietal columella. It is possible that the irregularity of septal development may be solely attribued to external, i.e., ecological factors.

\section{Montlivaltia $\mathrm{sp} .2$ Fig. 4 f,g.}

Material: 2 specimens: No: M45; 1 thin section.

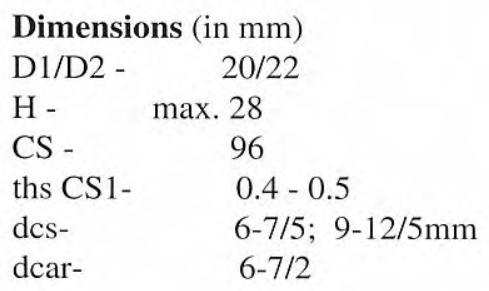

\section{Description}

Corallum subtrochoid. Calice rather deep. Subcircular central fossa. About 86 costosepta developed and arranged irregularly. At one side of the upper edge of the corallum, some S1 and S2 septa thick and strongly exsert. Between large septa, distinctly thinner radial elements of higher cycles are visible. In the section ca. $1.5 \mathrm{~cm}$ below the distal part of the corallum, all costosepta are equal on one side and are different in thickness on the other. Epitheca covering lateral surface in the form of transverse rings but not reach the edge of the calice.

\section{Remarks}

The specimens are not well preserved. Differences between M. multiformis and Montlivaltia sp. 2 are: irregularly developed septal apparatus and distinctly exsert S1 and S2 septa.

\section{CONCLUSIONS}

Montlivaltia multiformis, formerly reported in the Carpatho-Balkanic domain, is described in the Lower Aptian beds of the Jumilla-Yecla region (Prebetic domain of SE Spain). The specific identification of this form was based on: the development, number and symmetry of radial elements, the diameter and density of septal trabeculae and carinae, and the density of endothecal elements. The shape of the coralla is not considered taxonomically significant but a reflection of environmental conditions. Montlivaltia multiformis shows some affinity to M. icaunensis and M. burckhardti and is a possible junior synonym of the latter species. In SE Spain, Montlivaltia multiformis occurs in relatively high density assemblages. Marly sediments and sedimentological features indicate a circalittoral setting. It is found in association with closely related Montlivaltia species (left in open nomenclature) and Pseudocoenia sp. (an hermatypic form). In the outcrop in Tirnovo (Bulgaria), Montlivaltia specimens occur in the marls as monospecific elements. Owing to its stratigraphic position in Bulgaria, Romania and SE Spain, Montlivaltia multiformis appears as a potential marker of the Lower Aptian Tethys European margin.

\section{ACKNOWLEDGEMENTS}

We are grateful to Prof. E. Roniewicz for kindly permitting us to examine specimens of Montlivaltia multiformis from Balkan Aptian sediments and for discussion. We also thank Ms J. Faber, M.Sc. (Laboratory of Electronic Microscopy, Zoological Institute, Jagiellonian University) for preparing the scanning electron micrographs and Mr. W. Obcowski (Institute of Geological Sciences, Jagiellonian University) for his help in preparing some of the photographs. We are also gratful to Profs. S. Rodriguez, S. Fernández, M. Company and $\mathrm{M}^{\mathrm{a}} \mathrm{L}$. Martínez for their constructive suggestions for revision. 
This paper is a contribution to Project PB 97-330 financed by the DGES (Spanish Ministry of Education and Research)

\section{REFERENCES}

Alloiteau, J. 1957. Contribution à la systématique des Madréporaires fossiles. Paris, 1-462.

Alloiteau, J. 1958. Monographie des Madréporaires fossiles de Madagascar. Annales géologiques de Madagascar, 25, 1-218.

Angelis d'Ossat, G. 1905. Fauna coralina del piso Aptiense de Cataluña. Memorias de la Real Academia de Ciencias y Artes de Barcelona, 5 (5), 67-73.

Arias, C., Masse, J.P. y Vilas, L. 1993. Caracterización secuencial y bioestratigráfica del Aptiense-Albiense p.p. en la Sierra de Sopalmo, Prebético interno (Prov. de Murcia). Boletín Geológico y Minero, 104, 603-612.

Bataller, J.R., 1947. Sinopsis de las especies nuevas del Cretácico de España. Memorias de la Real Academia de Ciencias y Artes de Barcelona, (3), 28 (12), 318-391.

Bugrova, I. J. 1991. Extraordinary large Montlivaltids (Scleractinia) of the Early Hauterivian of south-western Turkmenistan (in Russian). Ezhegodnik vsesoyuznogo paleontologicheskogo obshchestva, 34, 259-266, 298.

Cairns, S.D. and Wells, J.W. 1987. The suborders Caryophylliina and Dendrophylliina (Anthozoa: Scleractinia). Bulletin of American Paleontology, 93 (328), 23-43.

Coates, G. and Jackson, J. B. C., 1987. Clonal growth, algal symbiosis, and reef formation by corals. Paleobiology, 13, 363-378.

Dietrich, W. O. 1926. Steinkorallen des Malms und der Unterkreide im südlichen Deutsch-Ostafrica. Palaeontographica, (suppl. 7), 1, 43-62.

Eguchi, M. 1951. Mesozoic hexacorals from Japan. Science Reports of the Tohoku Imperial University. (2: Geology), 24, 1-96.

Fromentel, E. de. 1857. Description des polypiers fossiles de l'étage Néocomien. Bulletin de la societé des sciences historiques et naturelles de l'Yonne, 1-78.

Fromentel, E. de. 1863-1867. Zoophytes, Terrain crétacés (4-7). In: Paléontologie Française (Ed. A. d'Orbigny), 8, Paris (Masson), 145-336.

Gill, G. A. et Lafuste, J. 1971. Madréporaires simples du Dogger d'Afghanistan: Etude sur les structures de type «Montlivaltia». Mémoires de la Societé géologique de France, (N.S.), 50 (115), 1-40.

Hoedemaker, P. and Company, M. 1993. Ammonite zonation for the Lower Cretaceous of the Mediterranean region: basis for the stratigraphic correlation within IGCP Project 262. Revista Española de Paleontologia, 8, 117-120.

Koby, F. 1896-1898. Monographie des Polypier crétacés de la Suisse. Mémoires de la Societé paléontologique Suisse, 22-24, 1-100.

Kolosvary, G. 1954. Magyarorszag Kreta-Idoszaki koralljai
(Les coralliaires du Crétacé de la Hongrie). Annales de l'Institut Géologique de Hongrie, 42 (1), 64-131.

Kuzmicheva, E. I. 1963. New species of Early Valanginian solitary scleractinians from the Mountain Crimea (in Russian). Paleontologicheskiy Zhurnal, 3, 18-26.

Lathuiliere, B., 1996. Itinéraires astogéniques chez des coraux simples et coloniaux montlivaltiides du Bajocien de France. Geobios, 29, 577-603.

Liao, W. 1982. Mesozoic scleractinian corals from Xizang (Tibet). In: The series of the scientific expedition to the Qinghai-Xizang (Tibet) Plateau. Paleontology of Xizang (Tibet), 4, 151-183.

Liao, W. and Xia, J. 1985. Upper Jurassic and Lower Cretaceous Scleractinia from Bangoin district of northern Xizang (Tibet). Memoirs of the Nanjing Institute of Geology and Palaeontology, Acad. Sinica, 21, 119-174.

Masse, J.P. 1988. L'étagement bionomique des milieux benthiques néritiques actuels: signification bathymétrique et implications paléobathymétriques. Géologie Méditerranéenne, 15, 91-102.

Morycowa, E. 1971. Hexacorallia et Octocorallia du Crétacé inférieur de Rarau (Carpathes Orientales roumaines). Acta Palaeontologica Polonica, 16, 1-14.

Orbigny, A. d'. 1850. Prodrôme de Paléontologie stratigraphique universelle des animaux mollusques et rayonnés, (2), Paris (Masson), 1- 428.

Roniewicz, E. and Stolarski, J. 1999. Evolutionary trends in the epithecate scleractinian corals. Acta Palaeontologica Polonica, 44, 131-166.

Solomko, E. 1888. Die Jura- and Kreidekorallen der Krim. Verhandlungen der russiusch-kaiserlichen mineralogischen Gesellschaft zu St. Petersburg, (2), 24, 67-231.

Toula, F. 1889. Geologische Untersuchungen im centralen Balken. Denkschriften der Kaiserlichen Akademie der Wissenschaften, Mathematisch-Physikalische Klasse, 55, 1-108.

Trautschold, H. 1886. Le Néocomien de Sably en Crimée. Trudy Imperatorskogo St.-Peterburgskago Obshchestva Estestvoispytateley, 15 (4), 119-129.

Vilas, L., Masse, J. P. and Arias, C. 1993. Aptian Mixed Terrigenous and Carbonate Platforms from Iberic and Prebetic Regions, Spain. American Association Petroleum Geologists, Mem., 56, 243-253.

Vilas, L., Martín-Chivelet, J., Arias, C., Giménez, R., RuizOrtiz, P., Castro, J.M., Masse, J.P. and Estévez, A. 1998. Cretaceous carbonate platforms of the Spanish Levante. Sedimentary evolution and sequence stratigraphy. 15th International Sedimentological Congress. Alicante, Field trip guidebook, 293-315.

Wells, J. 1946. Some Jurassic and Cretaceous corals from Northern Mexico. Journal of Paleontology, 20, 1-7.

Zibrowius, M. 1988. Mise au point sur les Scléractiniaires comme indicateurs de profondeur (Cnidaria: Anthozoa). Géologie Méditerranéenne, 15, 27-47.

Manuscrito recibido: 8 de junio, 2000 Manuscrito aceptado: 20 de noviembre, 2000 